Original Article (short paper)

\title{
Sports and health from the perspective of physical education professionals
}

\author{
John Koumantareas ${ }^{1,2}$ (1), Rogério Cruz de Oliveira ${ }^{2}$ (16) \\ ${ }^{1}$ Serviço Social do Comércio, SESC, Santos, SP, Brazil; ${ }^{2}$ Universidade Federal \\ de São Paulo, UNIFESP, Baixada Santista, Santos SP, Brazil
}

\begin{abstract}
Aim: The objective of the study was to understand the conceptions of sports and health of Physical Education professionals working in a sports department of a municipality located in Baixada Santista region (São Paulo, Brazil) in the context of the non-training of athletes. Method: For that, a qualitative descriptive research was carried out with nine Physical Education professional, of both genders and in any age group, distributed in two sport centers. Semistructured interviews were conducted about sports and health. Data analysis occurred using non-a priori categories. Results: As a result, the conception of sports took place through three categories: sport as a movement; sport as a formation agent for citizenship; and sport as a competitive modality. In relation to health, three categories were also identified: health as well being; health as a quality of life; and health as body care. Conclusion: It is concluded that the diversity of conceptions found reflects the polysemy that involves sports and health, and, consequently, can result in a distinct pedagogical practice from these professionals, who, allocated in the same professional context, a sports department, can generate divergences.
\end{abstract}

Keywords: physical education; sports; health; education.

\section{Introduction}

Sports practice has occupied an increasing space in the imagination and everyday life of people. Literature shows that in one way or another, sports and its developments are present in the lives of thousands of people. Many possibilities to work with the theme are justified, above all, from the data regarding the number of countries affiliated to the International Olympic Committee, which is greater than members of the United Nations ${ }^{1}$.

Therefore, in addition to the strict and represented sports practice as organization and dispute of sports modalities itself; we need to understand that sports are also present in people's lives in different ways. As in conversation circles, or through the massive sports marketing strategies and the vastness in offering products, electronic games, among other diverse segments, all ruled by the specialized media or not. Thus, it clearly is a very important phenomenon present in all societies ${ }^{2}$.

In Brazil, it was noticed that since the mid-1970s, sports have gained a prominent place in society, strongly influenced by the movement "Esporte para Todos" (Sports for All). Given this context, sports practice has been widely disclosed and disseminated in an attempt of plurality, democratization, access, and permanence in the sport as a founded and legitimized content, including in the Brazilian educational system ${ }^{2,3,4,5}$.

Therefore, the concern at the time was that sports should be distributed to all, mainly to select the best ones from the perspective of physical preparation and development of performance athletes ${ }^{1,2,3,4,6}$.

Thus, it would behoove the formal education institutions to offer sport in an educational setting, whereas, the other sports manifestations would be beyond this environment. The attempt of Cartesian rationalization about the concept of sport and sports practice in Brazil had as its main supporter Manoel Tubino ${ }^{7,8}$, whose classification began to guide the actions and policies of the Brazilian Ministry of Sports. According to the author, the definition for that concept would be as follows:

- Performance sports and/or high-performance sports;

- Education sports and/or educational sports;

- Participation in sports and/or sports and leisure.

In the first case, sports should meet only the demands of sporting competition itself, a universe in which the form of strict sports dispute and athletic performance in order to prioritize performance as the ultimate goal $1^{11,2,3,4,6,9}$.

In the second case, as mentioned, sports and its practice would happen only in a formal school environment, having as its main protagonist Physical Education classes through the organization and dispute of school competitions, as well as through child and juvenile sports training classes ${ }^{2,9}$.

In the third and last case, the concept of a sport would be linked to the mass participation of society, approaching leisure, which can be conceptualized as the culture lived in people's free time ${ }^{10}$, in setting such as squares, parks, clubs or any other time and space where sports practice may be spread beyond any commitment to the performance sports.

However, the non-dialogical classification proposed by Tubino goes against the idea of plurality about sports practice. In this sense, we understand that sport is what is made of $\mathrm{it}^{11}$. Therefore, the concept of sport should not follow a rigid definition. It must be what one does of it, in order to consider the pedagogical intention of the one who teaches it and of the one who learns it, 
above all, understanding that any division is a simple didactic $\operatorname{organization}^{12,13}$, which can take on different meanings ${ }^{14}$.

Thus, health as an end reached throughout the process of sports training was highlighted and still is strongly disseminated by the various media strategies, as well as in Physical Education and sports professionals formation schools $\mathrm{s}^{2,3,5,15}$.

In this scenario, Physical Education and sports practice have the status of cause and effect, a condition that tends to disregard the sociocultural dynamics of its practitioners. For this, terms such as physical exercise, physical activity, and sports per se permeate people's imagination bringing values sometimes based on common sense. In this relation, it is thought that sports practice, beyond the intention of its actors, allows access and permanence to health. Such discourse, in its foundation, is imbued by the appeal of good physical fitness as the main model and of the fight against sedentarism ${ }^{16,17}$. Note that as an intrinsic value to this phenomenon, the incessant search for the so-called quality of life, represented, above all, by the escape of the so-called morbimortality standard ${ }^{18}$.

The tension point that arises here reinforces the condition of individual blame and immediacy about this theme. As stated, the media write about this daily, in order to raise people's awareness in detriment of a healthy lifestyle, reducing the understanding of health as a theme to a strictly pragmatic bias. Thus, sports as content receives sometimes the quality of the effective solution to all evils originating from the absence or low amount of body movement that people can experience. In short, to move is enhanced in this relationship and the one that does not practice any sports modality, consequently ceases to enjoy a good quality of life, all these are preponderant factors to a conception of happiness in postmodern society ${ }^{19}$.

It turns out that, in this interpretation, the health concept employed is based on the strict relation of the absence of diseases $^{20,21}$, reinforcing the biomedical model in its appropriation. The physical dimension to it is overrated, disregarding its discussion as a wider concept, that understands health as a complex network of social, psychological, access to work, leisure, food, housing and land tenure factors as some of the main social determinants of health ${ }^{22,23}$.

Given the employment of the immediate vision of the health concept considering the strict absence of disease, the old conception about the understanding of health as a complete biopsychosocial well-being is reinforced and perpetuated. This is because, from the understanding that a complete well-being for the human being, such as the idea of the quality of life, besides being relative and inherent to everyone's reality, is impossible, considering one's own process of biological regulation ${ }^{16,20,21,24,25}$.

In the media, this discourse reinforces the causal idea of sports practice and health promotion. In this sense, the meanings to such concepts break with the expanded understanding model in its performance. They stigmatize and reduce to the discourse of common sense what is relative to the appropriation and development of autonomy in a pedagogical model of permanent education in health.

Regarding this, this study consists of understanding the sports and health conceptions of Physical Education professionals working in a sports department of a municipality located in
Baixada Santista region (São Paulo, Brazil) in the context of non-training of athletes.

Assuming that conception is the act of conceiving the object ${ }^{26}$, we understand the relevance of the study facing the fact that sport and health constitute a strong binomial for Physical Education professionals.

\section{Method}

This study was submitted and approved by the Research Ethics Committee of the Federal University of São Paulo UNIFESP according to the opinion of N. 1017/2016 and in its development. In addition, it was reviewed and approved by a Research Ethics Committee prior to starting the study, and participants must provide written informed consent as stated by Brazilian Council of Ethics involving human subjects (CONEP/BR).

A descriptive research of qualitative approach was carried out, which does not allow isolated, piecemeal and narrow visions of reality ${ }^{27}$. Therefore, it relates to a study of status ${ }^{28}$, in the case of this study, the status of the sports and health concept for Physical Education professionals. Two public sports facilities were selected from a municipality in the Baixada Santista region, in São Paulo, mainly due to the numbers related to the involved professionals, amount of activities offered and their respective gratuity. Regarding their geographical location, one of them is situated in the sea coast zone of the city (zone 1), while the other is in the northwest zone of the city (zone 2).

The study interviewees were 9 (nine) Physical Education professionals of both sexes and of any age range. To this end, the following inclusion criteria were applied: Physical Education professionals with effective association in the sports department with at least 2 (two) years of professional formation in Physical Education and 1 (one) year experience in public sports projects. The only non-inclusion criterion adopted was not answering one or more questions of the study.

The recruitment of interviewees took place in August 2016. In all, 17 Physical Education professionals were contacted. Of these, 4 (four) did not meet some inclusion or exclusion criteria and 4 (four) did not agree to participate.

See below the information about the interviewees:

- Margarida: 63 years old, and 41 years experience in basketball (zone 1);

- Maria: 43 years old, and 10 years experience in the located gym, stretching and walking exercises (zone 1);

- José: 39 years old, and 8 (eight) years experience in adapted basketball, bodybuilding, and aquaerobics (zone 1);

- João: 34 years old, and 9 (nine) years experience in bodybuilding (zone 1);

- Rodrigo: 38 years old, and 10 years experience in bodybuilding (zone 1);

- Fernanda: 40 years old, and 8 (eight) years experience in swimming, aquaerobics, located gym, and stretching exercises (zone 2); 
- Joaquim: 29 years old, and 4 (four) years experience in swimming, aquaerobics, and water polo (zone 2);

- Jorge: 34 years old, and 4 (four) years experience in artistic gymnastics (zone 2);

- Daniel: 33 years old, and 4 (four) years experience in artistic gymnastics (zone 2);

All the interviews were held between August and October 2016 in the workplace of the professionals, at times previously agreed upon

The semi-structured interview, or conversation with purpose ${ }^{23}$, was applied as an instrument of data collection and focused on the study object. In the application and registration of the interviews, two questions were asked of the interviewees, as follows: How do you define sport? How do you define health?

These questions had as reference the work in sports and health as a pedagogical practice content of Physical Education professionals participating in the study.

Data analysis was done by non-a priori categories, which occur by the repeated process of reading the obtained data ${ }^{29}$. The "frequency" (repetition of contents common to most respondents) and "implied relevance" technique (an important subject that is not repeated in the report of other respondents ${ }^{29}$ was used in the elaboration of the categories since they are not excluding ${ }^{29}$.

\section{About the concept of sport}

The first question asked of the interviewees was about the concept of sport. When asked: "how do you define sport?", the entire construction process about it was considered.

The results' showed that sometimes the definition of concepts about what is done in their own professional practice, besides a complex exercise, translated the invitation to the resignification of the processes and action methodologies that are employed in their daily lives. Immediately, the dichotomy between the broad and narrow conceptions of sport ${ }^{2}$ was reinforced in the interviewees' words. Note that the broad concept considers cycling, walking, gymnastics, etc. as sports. "How many times have we not heard from people who say that 'their sport' is to go by bike to work, to dance on weekends or to walk on the beach?" (p. 38) ${ }^{2}$.

Thus, when we think immediately about the definition used, mainly from the perspective that, to practice a certain form of sport, it should not necessarily come imbued by exacerbated values of competition and highly institutionalized rules as a parameter of their process of living. In this sense, the set of answers about the concept of sport allowed us to identify three categories of analysis, as follows:

- $\quad$ Sport as a movement - 4 (four) interviewees

- $\quad$ Sport as a formation agent for citizenship - 4 (four) interviewees

- $\quad$ Sport as a competitive modality - 1 (one) interviewee.

The first category designed in the study was called "sport as a movement", understanding that any manifestation of sports practice is based on the simple and direct experimentation of human movement, whatever it may be. With this, sport as a movement makes possible that all people benefit from it and access a certain culture of values and relationships through the practice of sports in a symbiotic model of a possible sports culture $^{2,30}$.

At first, the search for excellence regarding motor gestures and success of sports practice was evidenced in the speeches of the actors as a possibility of understanding the human movement. However, the set of answers make us think that the movement spoken by the interviewees is the one that goes through its most diverse manifestation possibilities. As an example, such an impression can be seen based on the following parts of the interviews:

"Sport to me is... When you make a move... That depending, there, when you're there doing it... Has its specific characteristics" - Maria (interview 2).

“[...] Sport is a movement! Sport is a movement! It has its own guidelines, rules, limitations, and goals" - José (interview 3).

The previous data are close to the concept of "moving oneself", which brings in its essence the idea that to experience this movement, the moorings related to the techniques and different methodologies about the execution of the motor gestures are not necessary. In this conception, the precepts for a culture about the practice are articulated based on previous experiences of practitioners. However, it also allows the interpretation that this movement is allusive to professional sport, given the terms "specific characteristics", "guidelines", among others. In this aspect, the movement is that which passes through the institutionalized rules of the high-performance sport, which can and should be adapted so that its experience, in general, can happen based on the culture of the people 1,6,12,31 $^{\text {. }}$

Concerning the second category, here entitled: "sport as a formation agent for citizenship", note that the content obtained in the interviews record meets the ideal of a citizenship formation through sports, in which values of noble conjuncture are developed and disseminated throughout its practice. This condition, especially, is based on the following reports:

"[...] sport is people's integration. [...] it is a form of collective and individual interaction! [...] many are here, not only for exercise but for social integration". - João (interview 4).

"[...] I see the sport directed to 4 (four) aspects; I see sport as health; performance; educational; and initiation. And within these aspects, I believe that sport has the goal to form citizens." -Joaquim (interview 7).

In this part, issues such as cooperation, loyalty, and respect for the opponent through "fair play" deserve attention as a prime practical example in sports modalities themselves. In addition to this characteristic, the idea of the development of 
social and personal ascension capacities through sports practice was also evidenced. Therefore, we concluded that sports and its practice are close to the conception of the complex sociosportive teaching-experience-learning process ${ }^{1,6,12}$.

From this perspective, in addition to sports practice itself we can list the emphasis and strategy of the work of values, attitudes, and concepts near the perspective of integral education through sport, considering the empowerment, criticality and autonomy of sports protagonism. The third category related to the concept of sports was named: "sport as competitive modality". Such category appeared by "implicit relevance" interpretation and was based on the following:

"In my opinion, the sport is all modality that has
rules and is at a competitive level". - Fernanda
(interview 6).

Her conception is based exclusively on performance sport. It reinforces that any process of experience in sport has as goal training and preparation for competition and for physical performance. In this sense, it extols the concept of strict sports in detriment of a broad conception ${ }^{2}$ and as a complex sociocultural phenomenon $^{3,4}$.

Issues such as rigidity in the organization and dispute of sports competitions are overvalued and sports practice would be restricted to those who best master a certain technique of motor gestures execution and a certain standard of their excellence, including being reproduced in Physical Education school classes and corroborating for exclusion environments, as well as early sports specialization ${ }^{1,2,3,4,6}$.

When conceived in this perspective, sport is that which categorizes its practitioners according to the excellence of their experimentation. It restricts the possibilities of understanding in a broader view, going against all that reproduced in the postmodern discourses about sports practice and health since it reproduces the values of high-performance sport and reinforces the physical fitness bias in the definition of the said concept.

\section{About the concept of health}

Elaborating on the concept of health, the second question applied in the interview script was: "How do you define health?". Note that, in general, the work "with" and "in" health understood as the content of Physical Education took place in a kind of background in the pedagogical practice of the interviewees. Although there is some concern about the theme, its realization took place in a pragmatic and immediate perspective. Observe that, based on the data obtained, questions were raised about health promotion/prevention and rehabilitation as synonyms; about the dichotomy in the process of characterizing health as an intrinsic practice of sports; and especially, the emphasis on a model of complete biopsychosocial well-being.

In this sense, the set of answers about the concept of health allowed us to identify three categories of analysis, as follows:

- Health as well-being -4 (four) interviewees.
- Health as quality of life -3 (three) interviewees.

- Health as the strict body care -2 (two) interviewees.

With that, the first category presented is the one named: "health as well-being." It conveys the idea that people's health is directly conceived and influenced by the idea of full biopsychosocial well being in accordance with the health definition employed by the World Health Organization.

Such understanding of the concept of health is based on this study, given the following interview parts:

"[...] Health for me is physical, mental, emotional and social well-being when it [health] is balanced! In fact, health... is when you can have a good health - Maria (interview 2).

"[...] Health is when you have all of your natural functions, both physical and psychological, in 'good path ' [...] is when you have a physical, social and emotional well-being, for me, that is health!' John (interview 4).

In this sense, the definition used gained strength mainly from the understanding of health as a state achieved after a long journey through the various manifestations of the human movement - considering its strict relation with sports practice and reducing it to a utilitarian conception, reinforcing the relation of cause and effect, especially when health becomes understood as the absence of diseases. Still, note that the idea of complete physical well-being occurred, precisely, in an attempt to overcome the health concept as the absence of disease, so widely disseminated and defended by the WHO until the mid-1970s ${ }^{25}$.

However, in the literature, we see that the idea of complete well-being is controversial and unfinished, above all, to translate part of the biological identity and individuality of people, thus, received and it is still receiving harsh criticism about its functionality, reducing processes of meaning and conceptualization in health to an outdated and somewhat reductionist conception ${ }^{15,16,20,32,33,34,35}$.

Regarding the second category entitled "health as quality of life", it is one that is designed on the horizon of good physical condition as a premise for a better life. We have noticed the constant use of words and reflections about a good physical condition and the proper functioning of biological structures as attenuating of the condition of human beings, based on the following interview parts:

"Health for me is prevention! It is a prevention that I must have for a healthy old age. It is preventive." - Margarida (interview 1).

"Health? I would put it in parallel with the item quality; I need quality, so I can have health!' Rodrigo (interview 5).

Considering the interviews, note that the definition of the concept of health, in this category, emphasized the perspective 
of self-care. In addition to understanding the full biopsychosocial well-being, the individual subject is directly blamed for their own practice $^{20}$. In this context, health is understood in a simplistic view conceived from the emphasis on practices beyond the process of empowerment on the complexity of factors preponderant to an effective construction of the said concept.

Thus, reproducing the discourse of quality in the perspective of access and permanence to a health condition. As previously mentioned, the proposition of health quality is directly related to the idea of a healthy and qualified aging process. What should be criticized here, once again, is the superficiality in which the concept employed is defined. In this sense, the possibilities of appropriation and people's critics are invariably not considered, corroborating with the idea of health as the absence of diseases and encouraging a great example of the individual blame of people ${ }^{16,24}$.

The foundation of health as content aiming at people's individual longevity, besides the cause and effect relation, as well as a strong sense of guilt that classifies and organizes people by their level of movement practice, it is the one that, in the market, sells it as a product, a reward. "[...] health is not an object, a gift. Therefore, nobody can give health: the doctor does not give health, the Physical Education professional does not give health, the physical activity does not give health" $(\mathrm{p} .14)^{20}$. In this sense, the concept of health used in the most diverse human relations should be the one that places it as a result of a complex network of factors, which involves food, housing, education, income, environment, work, transportation, employment, leisure, freedom, physical activity, among others. This perspective permeates the Brazilian context through the realization of the VIII National Conference of Health ${ }^{36}$.

Clearly, from now on, the health-related approach as a theme requires a process of resignification about the actions and other methodological strategies employed in the daily life of health professionals, such as the physical educator. Thinking about their daily lives and bringing, as the main example the work of sports content with a focus on health - at least in the discourse is not to guide their lesson plans in the reproduction of extreme competition and values and beliefs about performance sports. Being aware of this process corroborates with a more effective pedagogical practice.

The third and last category present in relation to the concept of health was named: "health as the strict body care" and is based on the following sections:

\section{"[...] I believe that health is [sic] the capacities that people have to be able to practice their daily activities" - Joaquim (interview 7).}

\footnotetext{
"Health? What to say about health? Health is when the athlete practices the sports modality itself from a very young age, in this case, gymnastics. As they practice the modality, they stop being sedentary. When they [the athletes] do physical activities for more than 2 (two) times a week, this is already health for me. Unlike, for example, when you don't eat right, sleep right, does not have a routine with your own body "-Daniel (interview 9).
}

Differently from the conception of "health as a quality of life", it was noted that in the view of the interviewees the concept of health does not dialogue with the other spheres of the human condition, overvaluing the strict idea of self-care with the body. Indeed, it can be inferred that in the interview excerpt, the reflection of the human body, as well as about health, comes from the purely technical bias. Metaphorically, it justifies the symbiotic relationship of a machine seeking greater and better results ${ }^{2,15}$.

Therefore, sports practice based on the proper functioning of the human body emphasizes utilitarianism and concern regarding physical fitness as exclusive content in the respective declarations. The condition of the biomedical health model in a pedagogical practice in Physical Education and health is reinforced here. In this sense, the question remains: Is it worth struggling even if the body cannot stand it ${ }^{37}$.

The dichotomy unilaterally presented in the relationship between sports practice and health promotion, although it uses this discourse, brings it to another level, in an "implied" way. According to Kunz (2007) ${ }^{15}$,

Physical Education has always found its greatest legitimacy justifying health promotion, even if the practical priority is oriented toward sports. Thus, another of its great purposes, the detection, and promotion of sports talent, always reach only a minority, reinforcing the idea that others must be attended regarding health requirements or in other terms also called quality of life. Therefore, the health concern [...] ranges from improving aerobic capacity, strengthening the cardiopulmonary system, and strengthening the back-lumbar muscles so that children (smaller in general) can carry their increasingly heavy backpacks without major problems. In addition, certain therapeutic or prophylactic concerns often occur, which means that Physical Education professionals, with their students, perform postural corrections, special exercises for people with adiposity, respiratory deficiencies or excessively thin, that is, they promote the conditioning from a medical perspective (p. 175-176).

In the interim of medical perspective, the selected interviews excerpts, above all, referring to health as content, bring with them the conception of health work through sports practice as a remedy in health and disease processes. They comprise a certain "curative" character in the conception of doing as an end itself, reducing strategies, methodologies and the consequent critical reading and possibility of appropriation of concepts to the technic and immediate bias.

As a counterpoint, it must be understood that the most diverse teaching strategies and methodologies should be implied to expand the autonomy and empowerment of people in the process of developing their health, in a perspective that goes beyond the aforementioned cure. In this sense, critical reading about sports practice having health as a goal becomes crucial, breaking the paradigm of physical-sport performance and considering the multiplicity of actors involved in this issue. 
Nonetheless, it is important to note that Physical Education professionals were recognized as health professionals only in 1997, through Resolution $218^{38}$. This means that professional training in Physical Education is still incipient in health ${ }^{39,40,41}$, which in part justifies the arguments of the volunteers.

\section{Conclusion}

The conceptions of sport and health for Physical Education professionals working in a sports department of a municipality located in Baixada Santista region (São Paulo, Brazil) in the context of the non-formation of athletes were built through the plurality of ideas, revealing a multiplicity of discourses. In this regard, in large part, it allows us to infer in the attempt of a dialogical vision between the concepts of sport and health preponderant to their extended dimensions. Even though indirectly, and without the effective operation of a public policy that meets the demands inherent to the study concern, what is seen in the practical performance of volunteers is the belief about the inseparability between sport and health as teaching strategy and methodology.

Therefore, the conceptions diversity reflects the polysemism involving sports and health, and, consequently, resulting in a distinct pedagogical practice of these professionals, who, allocated in the same professional context (a sports department), can generate divergences. It does not affirm the existence of a problem, but it certainly shows a limitation that the Physical Education area has not yet overcome. The interface with the different fields of knowledge has produced for over 30 years divergences in the conception of the field itself, which reflects in other themes, including sports and health.

Thus, it becomes necessary to systematically understand the subject, considering the complexity of the human being in what refers to the processes of development of its autonomy in the construction and significance of the concepts of sport and health that each individual assumes as preponderant to his/ her practice, whether for health purposes or not. In this sense, the polysemism of the meanings demonstrated in this study reveals the unique need to think about the pedagogical practice in Physical Education and sport in an extended and provocative perspective regarding a plural and effective professional activity.

The challenges are many, but on the other hand, the current situation has revealed favorable scenarios for changes, given the investment of public health policies towards the valuation of corporal practices. In the last 10 years in Brazil, what was exclusive to state or municipal sports departments - the debate of sport and physical activity as a promoter of health and quality of life - has gained new arguments towards the production of people care. So what we have is an interdisciplinary door of study and intervention.

\section{References}

1. Paes RR, Balbino HF. A pedagogia do esporte e os jogos coletivos. In: Esporte e Atividade Física na Infância e Adolescência: uma abordagem multidisciplinar, 2nd edition, 1st reprint. Porto Alegre, Artmed; 2011. p.73-83.

2. Kunz E. Transformação Didático-Pedagógica do Esporte, 8th edition. Ed. Ijuí, Unijuí, 2016.

3. Bracht V. Educação Física e Aprendizagem Social, 2nd edition. Ed. Porto Alegre, Magister, 2005a.

4. Bracht V. Sociologia Crítica do Esporte: uma introdução 3th edition. Ed. Ijuí, Unijuí, 2005b.

5. Castellani Filho L. Educação Física no Brasil: a história que não se conta, 19th edition, 5th reprint. Ed. Campinas, Papirus, 2015.

6. Paes RR, Balbino HF, editors. Pedagogia do Esporte: contextos e perspectivas. Ed. Rio de Janeiro, Guanabara Koogan, 2005.

7. Tubino MJG. O Que é Esporte, 3th edition. Ed. São Paulo, Brasiliense, 2006.

8. Tubino MJG. Estudos Brasileiros Sobre o Esporte: ênfase no esporte educação. Ed. Maringá, Eduem, 2010.

9. Oliveira RC. "Não levo jeito, professor..." In: Educação Física Escolar: olhares a partir da cultura. Campinas, Autores Associados; 2010. p.87-100.

10. Marcellino NC, editor. Políticas Públicas de Lazer. Ed. Campinas, Autores Associados, 1996.

11. Parlebás P. Perspectivas para uma educación física moderna. Ed. Andalucia, Unisport, 1987.

12. Paes RR, Montagner PC, Ferreira HB. Pedagogia do Esporte: iniciação e treinamento no basquetebol. Ed. Rio de janeiro, Guanabara Koogan, 2015.

13. Scaglia AJ, Reverdito RS. Pedagogia do Esporte: jogos coletivos de invasão. Ed. São Paulo, Phorte, 2009.

14. Luguetti CN, Tsukamoto, MH, Dantas LT. Aspectos didático-pedagógicos. In: Esporte Infantojuvenil: treinamento a longo prazo e talento esportivo. São Paulo, Phorte; 2011. p.135-150.

15. Kunz E. Ministério da Saúde Adverte: viver é prejudicial à saúde. In: A saúde em debate na educação física - volume 3. Ilhéus, Editus; 2007. p.173-186.

16. Devide FP. Educação Física, Qualidade de Vida e Saúde: campos de intersecção e reflexões sobre a intervenção. Movimento. 2002; 8 (2): 77-84.

17. Ferreira MS, Castiel LD, Cardoso MHCA. Atividade Física na Perspectiva da Nova Promoção da Saúde: contradições de um programa institucional. Ciênc. saúde coletiva. 2011; 16 (1): 865-72.

18. Costa FF, Garcia LMT, Nahas MV. A Educação Física no Brasil em Transição: perspectivas para a promoção da atividade física. Rev. bras. ativ. fís. saúde. 2012; 17 (1): 14-21.

19. Bracht V. Educação Física \& Saúde Coletiva: reflexões pedagógicas. In: As Práticas Corporais no Campo da Saúde. São Paulo, Hucitec; 2013. p.178-196.

20. Carvalho YM. Atividade física e Saúde: onde está e quem é o "sujeito" da relação? Rev Bras Ciênc Esporte. 2001; 22 (2): 9-21.

21. Rabello LS. Promoção da Saúde: a construção social de um conceito em perspectiva com o SUS. Ed. Rio de Janeiro, Fiocruz, 2010.

22. Buss PM, Pelegrinni Filho AA. A Saúde e seus Determinantes sociais. Physis. 2007; 17 (1): 77-93.

23. Minayo MCS. O Desafio do Conhecimento: pesquisa qualitativa em saúde, 14th edition. Ed. São Paulo, Hucitec, 2014.

24. Czeresnia D. O Conceito de Saúde e a Diferença entre Prevenção e Promoção. In: Promoção da Saúde: conceitos, reflexões tendências. Rio de Janeiro, Fiocruz; 2003. p.39-53. 
25. Segre M, Ferraz FC. O Conceito de Saúde. Rev Saúde Pública. 1997; 31 (5): 538-42.

26. Abbagnano N. Dicionário de Filosofia, 5th edition. Ed. São Paulo, Martins Fontes, 2007.

27. Triviños ANS. Introdução à Pesquisa em Ciências Sociais: a pesquisa qualitativa em educação, 18th reprint. Ed. São Paulo, Atlas, 2009.

28. Thomas JR, Nelson JK, Silverman S. Métodos de pesquisa em atividade física, 6th edition. Ed. Porto Alegre, Artmed, 2012.

29. Campos JGC. Método de Análise de Conteúdo: ferramenta para a análise de dados qualitativos no campo da saúde. Rev. Bras. Enferm. 2004; 57 (5): 611-4.

30. Daolio J. Da Cultura do Corpo, 12th edition. Ed. Campinas, Papirus, 2007.

31. Daolio J. Futebol, cultura e sociedade. Ed. Campinas, Autores Associados, 2005.

32. Devide FP. Educação Física e Saúde: em busca de uma reorientação para sua práxis. Movimento. 1996; 3 (5): 44-55.

33. Minayo MCS. Saúde como responsabilidade cidadã. In: A Saúde em Debate na Educação Física - volume 2. Blumenau, Nova Letra; 2006. p.93-102.

34. Pacheco PFL, Tirintan MM, Oliveira RC. A Produção de Conhecimento e o Conceito de Saúde Numa Graduação em Educação Física. Salusvita. 2016; 35 (2): 259-78.

35. Palma A, Estevão A, Bagrichevsky M. Considerações teóricas acerca das questões relacionadas à promoção da saúde. In: A Saúde em Debate na Educação Física. Blumenau, Edibes; 2003. p.15-32.

36. Brasil. Conferência Nacional de Saúde, VIII, 1986 Brasília. Relatório Final. Brasília: Ministério da Saúde, 1986. Available from: http://conselho.saude.gov.br/biblioteca/Relatorios/relatorio_8. pdf. [Accessed 23th April 2016].

37. Brodtmann D. Gesundheit - mer als eine sinnperspektive für den sportunterricht? apud Kunz E. Ministério da Saúde Adverte: viver é prejudicial à saúde. In: A Saúde em Debate na Educação Física - volume 3. Ilhéus, Editus; 2007. p.173-186.

38. Brasil. Conselho Nacional de Educação. Resolução CNE/CP n.218, de 06 de março de 1997. Diário Oficial [da] República Federativa do Brasil, Brasília, Brasil, n.83, p.1, 5 maio 1997, Seção 1.

39. Ferreira SE, Guerra RLF, Pacheco PFL, Gomes RJ, Azevedo PHSM, Oliveira RC. Formação profissional em Educação Física e saúde na Universidade Federal de São Paulo. Revista Brasileira de Atividade Física \& Saúde. 2013; 18 (5): 646-51.

40. Oliveira LC, Rossit RAS, Oliveira RC. Inserção profissional dos egressos de um curso de educação física com ênfase na formação em saúde. Trabalho, Educação e Saúde. 2018; 16 (1): 305-18.

41. Oliveira RC, Andrade DR. Formação profissional em Educação Física para o setor da saúde e as diretrizes curriculares nacionais. Pensar a Prática. 2016; 19 (4): 721-33.

\section{Corresponding author}

\section{Rogério Cruz de Oliveira}

Human Movement Sciences Department, Universidade Federal de São Paulo, Campus Baixada Santista, Rua Silva Jardim 136, Cep: 11015-020, Santos,SP, Brazil.

E-mail: rogerio.unifesp@gmail.com

Manuscript received on April 17, 2018

Manuscript accepted on August 23, 2018

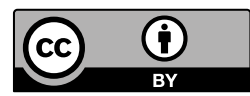

Motriz. The Journal of Physical Education. UNESP. Rio Claro, SP, Brazil - eISSN: 1980-6574 - under a license Creative Commons - Version 3.0 